\title{
Promoting Renewable Energy in the EU: Shifting Trends in Member State Policy Space
}

Daniel Behn, ${ }^{1}$ Ole Kristian Fauchald ${ }^{2}$ and Laura Létourneau-Tremblay ${ }^{3}$

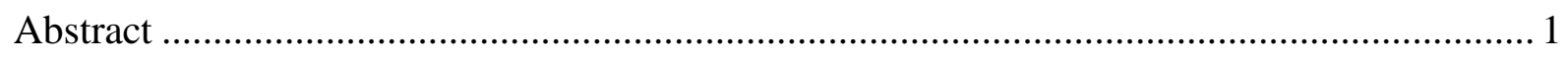

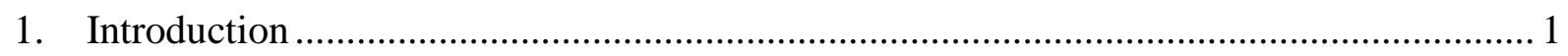

2. Shifting Trends in EU Policies on the Promotion of Renewable Energy .......................... 2

3. The Need for Change - Case Studies on Feed-In Tariffs .............................................. 6

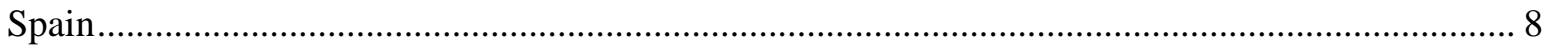

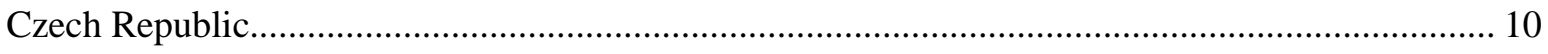

Italy

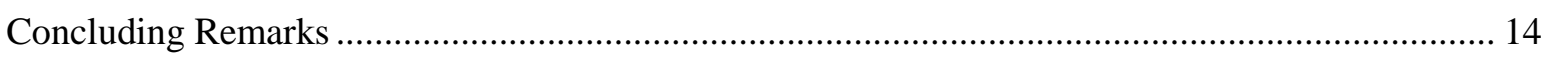

4. Scaling Back Incentives and the Investment Treaty Problem........................................ 15

5. The ‘Europeanization’ of Renewable Policy - Remedies to Address Market Distortions20

6. Conclusions - Towards an EU-wide Policy on the Promotion of Renewable Energy? ... 24

\begin{abstract}
:
Member States have sought to implement European Union (EU) initiatives on the promotion of renewable energy for almost 20 years now. However, some Member States are now finding that some of these very policy initiatives on renewable energy promotion have the capacity to conflict with these same Member States' other EU and international obligations, such as in the areas of international trade, foreign investment protection, and the functioning of the internal energy market. This article will provide an historical progression of EU laws and policies concerning the promotion of renewable energy generation, identify many of the factors inhibiting or challenging the achievement of EU renewable energy policy goals, and consider whether the proposed shifts in renewable energy promotion policy are likely to be effective in addressing these challenges.
\end{abstract}

\section{Introduction}

Member States of the European Union (EU) have sought to promote renewable energy generation as a means for meeting international and regional (EU) obligations to mitigate climate change; and it is now some of these very policy initiatives that are coming under attack when they might conflict with a Member State's other international and EU obligations, such as in the areas of international trade, foreign investment protection, and the

\footnotetext{
${ }^{1}$ Postdoctoral Researcher, PluriCourts, Faculty of Law, University of Oslo.

${ }^{2}$ Professor of Law, PluriCourts, Faculty of Law, University of Oslo.

${ }^{3}$ Researcher, PluriCourts, Faculty of Law, University of Oslo.
} 
functioning of the internal energy market. Member States of the EU are under cross-fire in regard to how they promote and incentivize renewable energy. Member States are increasingly challenged by other Member States, EU institutions - especially the European Commission (Commission), the Court of Justice of the European Union (CJEU), and investment treaty arbitration tribunals.

In implementing national policies on the promotion of renewable energy generation, all Member States have the goal of achieving national binding targets mandated under the 2009 Renewable Energy Directive (2009 Directive). ${ }^{4}$ While these targets are binding, the means by which a Member State achieves the targets are flexible, uncoordinated, and relatively isolated from an EU-wide policy. Given some of the problems in implementing a renewable energy promotion policy at the EU level, the Commission is currently working to correct what it sees as problems that have risen in regard to the autonomous development of renewable energy policies at the Member State level. Of primary importance is the design of support schemes. These have demonstrated important successes, but have also evidenced a number of policy failures.

As will be further explored, Member State support schemes for the incentivization of renewable energy have led to market distortions, state aid investigations, and exposure to potential responsibility under international investment agreements (IIAs). These issues have highlighted a need for greater policy coordination between the EU and its Member States. For the Commission, a 'Europeanization' of support schemes is needed to achieve the policy goals that are about to be set at the EU level on the promotion of renewable energy.

To address many of these issues, the Commission has been active in: (1) modifying the approach to the promotion of renewable energy generation; (2) modifying the approach to state aid; (3) criticizing some Member State policies on over-incentivization (and subsequent revocation of support); (4) challenging Member State refusal to subsidize non-national producers; and (5) attacking the validity of intra-EU IIAs and the enforcement of arbitral awards based on intra-EU IIAs. But EU institutions are also concerned about the principle of subsidiarity and the need to allow Member States flexibility in designing national policies to promote renewable energy. In looking at these issues, this article will examine the historical progression of EU laws and policies concerning the promotion of renewable energy generation, identify many of the factors inhibiting or challenging the achievement of EU renewable energy policy goals (highlighted above), and consider whether the proposed shifts in renewable energy promotion policy are likely to be effective in addressing these challenges while allowing sufficient policy space to Member States.

\section{Shifting Trends in EU Policies on the Promotion of Renewable Energy}

Promoting the production of renewable energy has been a high priority for the EU since the 1990s. ${ }^{5}$ In its 1997 White Paper, the Commission set a community strategy and action plan for renewable energy emphasizing the importance of promoting and further developing the

\footnotetext{
${ }^{4}$ European Parliament and the Council, Directive 2009/28/EC of 23 April 2009 on the promotion of the use of energy from renewable sources and amending and subsequently repealing Directives 2001/77/EC and 2003/30/EC, OJ L 140, (05 June 2009), http://eur-lex.europa.eu/legal-content/EN/TXT/?uri=celex:32009L0028 (accessed 15 January 2017).

${ }^{5}$ For further details, see Angus Johnston \& Guy Block, EU Energy Law (Oxford University Press 2012).
} 
renewable energy sector in the EU. ${ }^{6}$ Flowing from this White Paper, the first Directive on the promotion of electricity produced from renewable energy sources (2001 Directive) was adopted. $^{7}$ This Directive set a target of a twelve percent share of renewable energy in the overall energy consumption of the EU by $2010 .{ }^{8}$ To achieve this target, Member States were given non-binding national targets. ${ }^{9}$ In addition, the 2001 Directive introduced support schemes and guarantees of origin aiming at supporting the achievement of the target. Considering the limited experience with support schemes at that time, the 2001 Directive did not include a harmonized support mechanism but simply required the Commission to monitor the developments and report on the experience gained with the implementation of support schemes. $^{10}$

In 2007, the Commission presented its Renewable Energy Roadmap highlighting the failure to achieve the agreed target in renewable energy due to 'a policy failure and a result of the inability or the unwillingness to back political declarations by political and economic incentives'. ${ }^{11}$ As a way forward, the Commission proposed the adoption of a binding target and increasing the overall level of renewable energy from final energy consumption to twenty percent by 2020. Following the Commission proposal, a new Directive on renewable energy was adopted in 2009. ${ }^{12}$ This Directive introduced a common framework with national binding targets calculated on the basis of the 2005 share of renewable energy in each Member State. ${ }^{13}$ According to the 2009 Directive, Member States were allocated binding targets set at the EU level and aimed at meeting the EU-wide goal of achieving twenty percent of its total energy consumption from renewable sources by 2020. In setting these binding targets, the EU was purposefully silent (for the most part) on mandating the ways and means that these renewable targets would be met by each Member State. This policy is consistent with the EU's subsidiarity principle and gives Member States a great degree of flexibility in designing their renewable energy promotion policies. ${ }^{14}$ The binding nature of the renewable energy targets stipulated in the 2009 Directive has also led to a considerable increase in investment in green electricity in the EU. ${ }^{15}$

\footnotetext{
${ }^{6}$ European Commission, Energy for the Future: Renewable Sources Of Energy - White paper for a Community Strategy and Action Plan, COM(97)599, (26 November 1999), http://europa.eu/documents/comm/white_papers/ pdf/com97_599_en.pdf (accessed 15 January 2017).

${ }^{7}$ European Parliament and the Council, Directive 2001/77/EC of 27 September 2001 on the promotion of electricity produced from renewable energy sources in the internal electricity market, OJ L 283, (27 October 2001), http://eur-lex.europa.eu/legal-content/EN/ALL/?uri=CELEX:32001L0077 (accessed 15 January 2017).

${ }^{8}$ Ibid., Art. 3(4).

${ }^{9}$ Ibid., Art. 3.

${ }^{10}$ Ibid., Art. 4; see also CJEU C-66/13, Green Network SpA, §§ 51-55 (2014); and CJEU C-195/12, IBV \& Cie, $\S \S 63-65$ (2013).

${ }^{11}$ European Commission, Communication to the European Parliament and the Council, Renewable Energy Road Map - Renewable Energies in the 21st Century: Building a More Sustainable Future, COM(2006) 848, 8, (10 January 2007), http://eur-lex.europa.eu/legal-content/EN/TXT/?uri=celex:52006DC0848 (accessed 15 January 2017).

${ }^{12}$ European Parliament and the Council, Directive 2009/28/EC.

${ }^{13}$ Ibid., Art. 3(1); Annex I, Part A.

${ }^{14}$ Marjan Peeters, Governing Towards Renewable Energy in the EU: Competences, Instruments, and Procedures 21 Maastricht Journal of European and Comparative Law 1, 49-50 (2014).

${ }^{15}$ Kim Talus, Renewable Energy Disputes in the Europe and Beyond: An Overview of Current Cases, OGEL 3, 4 (2015).
} 
Due in 2010, the 2009 Directive required each Member State to submit a National Renewable Energy Action Plan to the Commission showing how they intended to achieve their binding national targets. ${ }^{16}$ These plans allow Member States the flexibility to decide how they will achieve their targets and foster the necessary stability for investors. A reporting system ensuring the monitoring of the progress was also established. ${ }^{17}$ The 2009 Directive encourages cooperation through cross-border projects, support schemes, and statistical transfer of energy from renewable sources between Member States. ${ }^{18}$ The 2009 Directive reformed the system of guarantees of origin introduced by the 2001 Directive. The guarantees of origins were standardized and considered as a tradable good. ${ }^{19}$

Much has been achieved with regards to the targets set for development of the renewable energy sector since the adoption of the 2009 Directive; ${ }^{20}$ but the EU has now started to look beyond 2020. In early 2014, the Commission published its 2030 Climate and Energy Policy Framework (2030 Policy Framework), which sets out new energy and climate objectives in the period from 2020 to $2030 .^{21}$ The 2030 Policy Framework sets an EU target of at least twenty-seven percent of total energy consumption from renewable sources by 2030. This will be a binding target at the EU level which will not be translated into binding targets at the national level. This move away from binding national targets has been criticized by certain members of the European Parliament as 'short-sighted' and 'unambitious'. ${ }^{22}$ According to the Commission and the European Council (Council), however, an EU-wide binding target will continue to allow Member States the flexibility to design their renewable energy policies in a manner specific to their circumstances, while at the same time strengthening regional cooperation between Member States and assist the EU in moving closer to a single energy market. ${ }^{23}$ With this common approach, the EU aims at ensuring stronger investment stability, greater transparency, coherence and coordination across the EU. ${ }^{24}$ This position was also endorsed by Advocate General (AG) Bot in Green Network: a CJEU case concerning the obligation to purchase green certificates on energy produced outside the EU. AG Bot stated

\footnotetext{
${ }^{16}$ European Parliament and the Council, Directive 2009/28/EC, Art. 4.

${ }^{17}$ Ibid., Art. 22.

${ }^{18}$ Ibid., Arts. 6-11.

${ }^{19}$ Ibid., Art. 15.

${ }^{20}$ European Commission, Renewable Energy Progress Report, COM(2015) 293 Final, (15 June 2015).

${ }^{21}$ The 2030 Policy Framework was endorsed by the European Council on 24 October 2014; see European Council, Conclusions, EUCO 169/14, (24 October 2014), http://www.consilium.europa.eu/uedocs/cms_data/ docs/pressdata/en/ec/145397.pdf (accessed 15 January 2017). In July 2015, the Commission started the legislative process necessary to implement post-2020 commitments into EU law: see European Parliament, Post2020 Reform of the EU Emissions Trading System, Briefing: EU Legislation in Progress, (18 September 2015), http://www.europarl.europa.eu/RegData/etudes/BRIE/2015/568334/EPRS_BRI\%282015\%29568334_EN.pdf (accessed 15 January 2017).

22 See EurActiv, Parliament Backs Strong EU Stance on 2030 Clean Energy Goals, (6 February 2014), http://www.euractiv.com/energy/meps-confirm-ambitious-stance-20-news-533298 (accessed 15 January 2017).

${ }^{23}$ European Commission, Communication from the Commission to the European Parliament, the Council, the European Economic and Social Committee and the Committee of the Regions, A Policy Framework for Climate and Energy in the Period from 2020 to 2030, COM(2014) 15, 3, (22 January 2014), http://eur-lex.europa.eu/ legal-content/EN/TXT/PDF/?uri=CELEX:52014DC0015\&from=EN (accessed 15 January 2017).

${ }^{24}$ Ibid., 6; see also European Commission, 2030 Energy Strategy, http://ec.europa.eu/energy/en/topics/energystrategy/2030-energy-strategy (accessed 15 January 2017).
} 
that the EU's new policy towards renewable energy will allow for 'a new more collective, coherent and coordinated approach to the promotion of green energy' ${ }^{25}$

By adopting an EU-level binding target, the Commission aims at stimulating the development of renewable energy at the EU level while still giving Member States sufficient flexibility in the design and implementation of their renewable energy policies. However, a primary driver in the EU's recent shift in renewable energy policy appears aimed at facilitating the 'Europeanization' of support schemes and in decreasing barriers preventing the completion of the internal energy market. The Commission has also emphasized that new renewable energy promotion plans of Member States must take into account 'the need to comply with competition and State aid rules to avoid market distortions and ensure cost-effectiveness' ${ }^{26}$

Hence, while the new approach provides Member States flexibility in fixing their targets, it may at the same time reduce their flexibility to decide how they support the development of renewable energy within their borders. ${ }^{27}$ According to the Commission, technology neutrality and equal treatment of all renewables without sector specific targets or support schemes across the EU could improve short to medium term cost-effectiveness. ${ }^{28}$ The Commission has emphasized that the 2030 Policy Framework is focused, inter alia, on strengthening regional cooperation, the further integration of the internal energy market, and undistorted competition. ${ }^{29}$ To ensure the monitoring of an EU-wide target, the Commission has proposed a transparent governance system that will assess national plans with the aim of enhancing predictability for investors and fostering regional cooperation between Member States. ${ }^{30}$ While the drive to liberalize and integrate renewable energy markets in the EU has been historically left to the Member States to implement, the 2030 Policy Framework signals a significant shift towards a more centralized coordination of policies by the Commission. ${ }^{31}$

In line with many of the policy goals outlined in the 2030 Policy Framework, the Commission released its new draft renewable energy directive (new Directive) on 30 November 2016, ${ }^{32}$ which confirmed the intent of the EU to pursue EU-wide targets and to limit the use of support schemes. However, it remains unclear exactly how the new Directive will guarantee compliance with the new EU-wide binding renewable energy target; and how support schemes can be designed so as to ensure their compliance with EU state aid rules. These issues remain of critical importance given the problems that Member States have encountered with the implementation of their support for renewable energy under the current Directive.

\footnotetext{
${ }^{25}$ Opinion of AG Bot, CJEU C-66/13, Green Network SpA, § 63 (2014).

${ }^{26}$ European Commission, A Policy Framework for Climate and Energy, supra n 23, 6-7.

${ }^{27}$ Marjan Peeters \& Thomas Schomerus, Regional Renewable Energy: A String of Legal and Financial Challenges, in Marjan Peeters \& Thomas Schomerus (eds.), Renewable Energy Law in the EU: Legal Perspectives on Bottom-up Approaches, 284 (Cheltenham: Edward Elgar 2014).

${ }^{28}$ European Commission, Commission Staff Working Document, Executive Summary of the Impact Assessment, SWD(2014) 16 final, 2, 13-14 (22 January 2014), http://ec.europa.eu/smart-regulation/impact/ia_carried_out/ docs/ia_2014/swd_2014_0016_en.pdf (accessed 15 January 2017).

${ }^{29}$ European Commission, A Policy Framework for Climate and Energy, supra n 23, 3.

${ }^{30}$ Ibid., 12-13; European Council, Conclusions, supra n 21, 9.

${ }^{31}$ Kim Talus, EU Energy Law and Policy: A Critical Account, 286 (Oxford University Press 2013).

${ }^{32}$ European Commission, Proposal for a Directive of the European Parliament and of the Council on the promotion of the use of energy from renewable sources (recast), COM(2016) 767 final (30 November 2016), https://ec.europa.eu/energy/sites/ener/files/documents/1_en_act_part1_v7_1.pdf (accessed 15 January 2017).
} 
For many Member States, the primary mode of support has come through feed-in tariff (FITs), feed-in premium (FIPs) or green certificate programs; and some of the components of these programs have become subject to state aid investigations in recent years. While these support schemes have worked in many Member States (e.g. Germany), they have, as we shall see, given rise to a number of problematic situations in many others (e.g. Spain, the Czech Republic, and Italy).

While the 2009 Directive provided Member States considerable latitude in the design and management of their support schemes, the new Directive, provides the EU with considerable oversight and monitoring authority over the ways in which Member States achieve renewable energy targets. However, what is missing in the new Directive is a common policy approach on the use of support schemes that would limit or prevent many of the missteps made by Member States under the current Directive. In the next section, we explore some of the problems with support schemes that have emerged under the 2009 Directive and to explain what role the Commission could play in mitigating some of these issues through the new Directive.

\section{The Need for Change - Case Studies on Feed-In Tariffs}

One of the primarily catalysts for the recent proposed shifts in the renewable energy policies of the EU has been the practice of support schemes for the promotion of renewable energy in a key number of Member States. These Member States over-incentivized their renewable energy support schemes initially and have had to withdraw or revoke much of the support for renewable energy investment that was originally on offer. While a large number of Member States have had to modify their support schemes in recent years, three particular Member States stand out for having to make drastic reforms to their renewable energy support schemes; and which have now led to a significant number of international disputes.

These Member States - Spain, the Czech Republic and Italy - all over-incentivized their renewable sector in the mid- to late 2000s, and have had to make drastic adjustments in the past few years. These modifications to their support schemes have resulted in investment treaty arbitrations being filed against them. In the following section, we have chosen to provide case studies on these three Member States because they are the only EU Member States to date that have become subject to investment treaty arbitrations as a direct result of the (mis)management of their renewable energy support policies. However, with that said, the modification of support schemes for renewable energy has occurred in a large number of Member States; and may lead to the initiation of investment treaty arbitrations in the future. For example, Romania, Estonia, Poland, Bulgaria, Slovakia, Latvia, Greece, Belgium, the United Kingdom, and France have all made significant modifications to their support schemes in recent years. ${ }^{33}$

\footnotetext{
${ }^{33}$ For more details, see Keep on Track 2020, Retroactive and Retrospective Changes and Moratoria to RES Support, (March 2015), http://www.keepontrack.eu/contents/publicationsbiannualnationalpolicyupdates versions/policy-briefing6-retroactive-and-retrospective-changes-and-moratoria-to-res-support.pdf (accessed 15 January 2017); CEER, Status Review of Renewable and Energy Efficiency Support Schemes in Europe in 2012 and 2013, (2015). EPIA, Retrospective Measures at the National Level and Their Impact on the Photovoltaic Sector, (10 December 2013), http://www.photon.info/ newsletter/document/83019.pdf (accessed 15 January
} 
As noted above, the 2009 Directive focuses on the consumption of energy within each Member State and at the European level. The most important means to achieve the targets on renewable energy have been the establishment of support schemes, such as FITs, FIPs, and green certificates. These measures are focused on different elements in the process of production, distribution and consumption of energy. As a very general starting point, support schemes that are targeted at producers or the transactions between producers and distributors (generally referred to as transmission system operators (TSOs) or distribution system operators (DSOs)) $)^{34}$ are likely to raise crucial issues regarding distortive market effects and 'leakage' (i.e. support schemes being enjoyed by foreign producers or consumers). Support schemes that are targeted at consumers or the transactions between TSOs/DSOs and consumers, on the other hand, are less likely to have such effects. Our preliminary study indicates that FITs and FIPs are focused on the transactions between electricity producers and TSOs/DSOs, while green certificates ${ }^{35}$ can tend to focus on the relationship between TSOs/DSOs and consumers. For this reason and due to the extensive resort to FITs, we have chosen to focus on FITs in our case studies.

In the European context, Germany's FIT program dates back to the 1990s, and was followed by a number of other FIT and FIP programs in the early 2000s. A FIT program aims at offsetting the higher cost of renewables technologies in relation to fossil fuels, and provides a stable all-inclusive price for electricity generated from renewable sources. ${ }^{36}$ A FIP (also called a green bonus) on the other hand is paid in addition to the market price. A FIP is considered to be more market-friendly than the FIT because the producer is exposed to market price risk. While each of these programs is specific to the EU Member State, they have a number of similar design features: (1) they provide an additional price (i.e. above the market price for electricity) paid for electricity produced from renewable energy sources; (2) the additional price is only paid on electricity actually 'fed-in' to the grid (i.e. submitted to the TSO/DSO); (3) tariffs are often differentiated according to characteristics of the production facility (i.e. its size, geographical location and energy source); (4) the tariff is guaranteed for a certain period of time, normally fifteen to twenty-five years; (5) the tariff price is set to digress over time; and (6) FIT and FIP schemes have increasingly been using local content

2017). Bulgaria, e.g., applied a ‘temporary’ thirty-nine percent grid access tax on all PV solar producers benefiting from the state’s FIT scheme. See PV Magazine, Bulgarian PV Industry Protests Limits on Renewable Energy Production, (4 July 2013), http://www.pv-magazine.com/news/details/beitrag/bulgarian-pv-industryprotests-limits-on-renewable-energy-production-updated_100011921/\#axzz3lf2lii19 (accessed 15 January 2017).

${ }^{34}$ European Parliament and the Council, Directive 2009/28/EC, Art. 2(4), Art. 2(6): 'transmission system operator' means a natural or legal person responsible for operating, ensuring the maintenance of and, if necessary, developing the transmission system in a given area and, where applicable, its interconnections with other systems, and for ensuring the long-term ability of the system to meet reasonable demands for the transmission of electricity; 'distribution system operator' means a natural or legal person responsible for operating, ensuring the maintenance of and, if necessary, developing the distribution system in a given area and, where applicable, its interconnections with other systems and for ensuring the long-term ability of the system to meet reasonable demands for the distribution of electricity.

${ }^{35}$ There exists a wide variety of schemes that can be labelled 'green certificates'. While some target producers requiring them to submit an amount of green certificates depending on their overall level of production, other schemes target TSOs/DSOs and require them to submit an amount of green certificates based on the amount of energy they transfer to consumers.

${ }^{36}$ It can also be discussed whether FITs may distinguish between different kinds of renewable energy, i.e. between well-established sources such as hydro-power and emerging sources such as wave or tidal energy. 
requirements for the production equipment, providing a bonus payment to those facilities that source a certain percentage of their equipment from within the EU. ${ }^{37}$

While there are a number of similarities among different FIT and FIP programs in the EU, there is one key difference that appears to be a key determinant in whether a particular program has been considered a success or not: the extent to which the programs overincentivized certain types of renewable technologies (in other words: under-estimated the amount of new investment that the support scheme would produce). This is a phenomenon that has been present for producers of electricity using solar energy (especially in the photovoltaic (PV) solar sector and to a less extent, the concentrated solar power (CSP) sector). ${ }^{38}$ Our case studies therefore focus on the solar sector in three select states which have all made major revisions to their renewable support schemes in the last five years and have spawned significant international litigation: Spain, the Czech Republic, and Italy.

\section{Spain}

Already in the 1980 the Spanish government encouraged the use of renewable energies. ${ }^{39}$ Spain introduced more specific measures to promote renewable energy in $2004{ }^{40}$ These measures offered investors either a fixed price FIT or a FIP. The FIT amounted to approximately thirty-two Eurocents per kilowatt/hour (kWh) for electricity produced from PV solar, ${ }^{41}$ and it was guaranteed for a period of twenty-five years after which it would be reduced by approximately twenty percent (for years twenty-six through forty). Under the legislation, the DSO was required to bear the cost of the FIT. These additional costs exceeded the regulated price that could be charged to consumers, resulting in a multi-billion Euro debt held by the state (called an 'electricity deficit'). ${ }^{42}$ In 2005, Spain enacted a renewable energy plan in accordance with the 2001 Directive. According to this plan, Spain set a target of achieving twelve percent of its total energy consumed from renewable sources by 2010 . Spain's share of electricity consumed from renewable sources was 8.3 percent in 2005 and reached 13.8 percent by 2010 .

\footnotetext{
${ }^{37}$ Member states with local content requirements as a component part of their support schemes include France, Italy, Greece, and Croatia. These local content requirements generally provide a bonus payment (on top of the FIT or FIP rate) for equipment sourced within the EU.

${ }^{38}$ As PV solar and CSP installations are regulated and supported under the same schemes, we use the term 'PV solar' to refer to both types of installations.

${ }^{39}$ For further details, see Iñigo del Guayo, Promotion of Renewable Energy Sources by Regions: The Case of the Spanish Autonomous Communities, in Marjan Peeters \& Thomas Schomerus (eds.), Renewable Energy Law in the EU: Legal Perspectives on Bottom-up Approaches, 54 (Cheltenham: Edward Elgar 2014).

${ }^{40}$ Royal decree 436/2004 establishing the methodology for the updating and systematisation of the legal and economic regime for electric power production in the special regime, 8 Legislation Development of the Spanish Electric Power Act, Published in the Official State Journal, B.O.E., Issue 75 (27 March 2004), http://www.areanet.org/fileadmin/user_upload/PACT/Laws/Spain_436_2004_english.pdf (accessed 15 January 2017).

${ }^{41}$ The FIP for PV solar amounted to about ten percent less than the FIT.

${ }^{42}$ Under the original plan, the amount of PV solar installed would be small enough that the additional costs could largely be absorbed by the DSO. However, the surge in the installation made it impossible to absorb the additional costs and it was at this point that the electricity deficit expanded significantly. The deficit is in excess of thirty billion Euro (and continues to grow). See also David Robinson, Pulling the Plug on Renewable Power in Spain, Oxford Energy Comment, Oxford Institute for Energy Studies, (2013), http://www.oxfordenergy.org/ wpcms/wp-content/uploads/2013/12/Pulling-the-Plug-on-Renewable-Power-in-Spain.pdf (accessed 15 January 2017).
} 
In May of 2007, Spain updated its program by increasing the tariff to approximately forty-six Eurocents/kWh for PV solar. ${ }^{43}$ This amendment created a cap on the amount of PV solar ${ }^{44}$ that could be installed. Once the cap was reached, regulators could adjust the FIT. While Spain had set a goal of installing 400 megawatts (MW) of PV solar by 2010, this was reached in early 2007; and by 2010, nearly 4000 MW had been installed. ${ }^{45}$

\section{Figure 1: Annual Installed PV Solar in Spain in MWh}

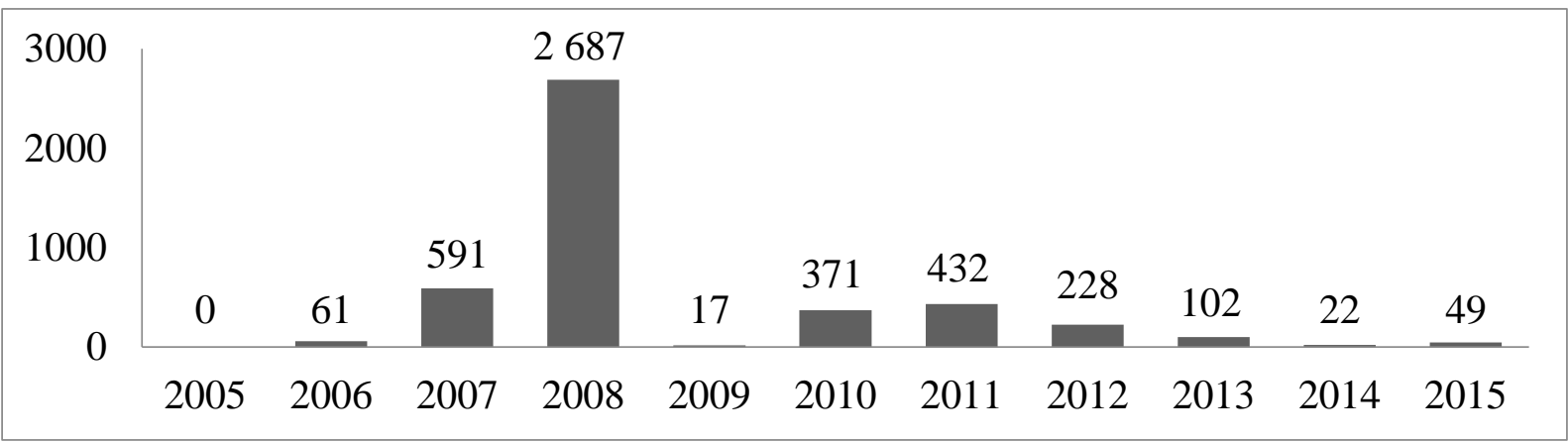

By late 2007, Spanish regulators knew that the deployment of PV solar installations was occurring so rapidly as to reach its targets three years ahead of schedule. When the Spanish legislature responded in September 2008, there had already been a dramatic surge in the amount of PV solar installed. The legislation modified the method for allocating FIT contracts and reduced the FIT in 2008. ${ }^{46}$ As follows from Figure 1 above, these changes provided significant disincentive for future PV solar installations. ${ }^{47}$ Spain continued to modify the support scheme during 2010: (1) the FIT was reduced by forty-five percent and the FIT after twenty-five years was withdrawn; ${ }^{48}$ (2) FIT contracts (including existing ones) were modified by limiting the number of hours that PV solar installations could operate and a grid access fee of approximately two Eurocents/kWh on electricity from PV solar installations was introduced. ${ }^{49}$ These changes reduced expected revenue from PV solar projects by about thirty percent. $^{50}$

In 2011, Spain submitted another renewable energy plan as mandated by the 2009 Directive by which it agreed to achieving twenty percent of its total energy consumption from

\footnotetext{
${ }^{43}$ National Energy Regulatory Commission, Legislation Development of the Spanish Electric Power Act, Royal decree 661/2007 regulating the activity of electricity production under the special regime, BOE 126, 73 (26 May 2007), http://bit.ly/1O9w2UR (accessed 15 January 2017).

${ }^{44}$ While the FIT program focused on energy generated from PV solar, it also included CSP and provided the same incentivization for both CSP and PV solar.

${ }^{45}$ Francisco Montoya, María Aguilera \& Francisco Manzano-Agugliaro, Renewable energy production in Spain: A Review 33 Renewable and Sustainable Energy Review 513-515 (2014).

${ }^{46}$ Royal decree 1578/2008 (26 September 2008).

${ }^{47}$ The changes reduced the net amount of installed PV solar in 2009 to almost nothing, before the installation picked up again in 2010.

${ }^{48}$ Royal decree law 1565/2010 (23 November 2010).

${ }^{49}$ Royal decree law 14/2010 (23 December 2010). While the increasing electricity deficit has been exasperated by the generous FIT program for PV solar, the electricity deficit in Spain has been a general problem for a long time and is tied to all sources of electricity.

${ }^{50}$ Pablo del Rio \& Pere Mir-Artiques, A Cautionary Tale: Spain’s Solar PV Investment Bubble, Global Subsidies Initiative 22 (2014), https://www.iisd.org/gsi/sites/default/files/rens_ct_spain.pdf (accessed 15 January 2017).
} 
renewable sources by $2020 .^{51}$ While PV solar continues to be a part of the renewable energy mix that will assist in Spain's achievement of its renewable energy targets, it remains only a small percentage of Spain's overall electricity consumption (3.2 percent in 2012).

To address the 'electricity deficit', legislation was passed in 2012 that placed a moratorium on the registration of new PV solar projects for an indefinite period, and that imposed an openended seven percent tax on all electricity generators from $2013 .^{52}$ In early 2013, the changes continued with legislation that terminated the FIT support scheme for all new renewable energy installations from $2014 .^{53}$

New legislation passed in 2013 and 2014 requires that FIT rates on future projects be based on an internal rate of return between five and 5.5 percent after taxes. ${ }^{54}$ This change means that any projects that were financed at a rate higher than five percent are likely to be unprofitable. The government originally envisioned support to PV solar projects to provide an internal rate of return of approximately seven percent, which would permit a 'reasonable rentability' on projects. $^{55}$ The internal rate of return on many projects prior to the series of legislative changes between 2008 and 2012 was between ten and fifteen percent. ${ }^{56}$

The PV solar sector in Spain has obviously experienced what can be considered a boom followed by a bust; and this bust has resulted in a number of lawsuits. At the national level, there have been at least fifty cases decided before the Spanish Supreme Court, all of which have been rejected. ${ }^{57}$ However, this is only the tip of the iceberg in that as many as 630000 appeals could be brought in the Spanish courts as a result of the modifications made to legislation. $^{58}$ At the European level, numerous complaints have been brought to the Commission by those who have invested in the PV sector in Spain, including one complaint brought by a group of 1500 investors requesting an investigation into the changes made by Spain and their consistency with EU law. ${ }^{59}$

\section{Czech Republic}

The FIT program established in the Czech Republic in 2002 only resulted in a few renewable energy projects as the FIT rates were too low. ${ }^{60}$ In 2005, the Renewable Energy Support Act

\footnotetext{
${ }^{51}$ Ministry of Industry and Tourism, Spain's National Renewable Energy Action Plan 2011-2020, 43 (30 June 2010), http://ec.europa.eu/energy/renewables/action_plan_en.htm (accessed 15 January 2017).

${ }^{52}$ Royal decree law 1/2012 (27 January 2012).

${ }^{53}$ Royal decree law 2/2013 (1 February 2013).

${ }^{54}$ Royal decree law 9/2013 (12 July 2013); Royal decree 413/2014 (6 June 2014).

${ }^{55}$ For a definition of 'reasonable rentability' as defined in Art. 19 of Royal decree 413/2014, Electricity Promotion in Spain, SRES Legal (7 July 2014).

${ }^{56}$ del Rio and Mir-Artiques, A Cautionary Tale, supra n 50, 12.

57 See http://www.poderjudicial.es/search/index.jsp, search terms: ley 14/2010, ley 1565/2010 (accessed 15 January 2017). See also Blanca Lopez, Spain's Supreme Tribunal Rules Against PV System Owners, PV magazine, (25 January 2016), http://www.pv-magazine.com/news/details/beitrag/spains-supreme-tribunal-rulesagainst-pv-system-owners_100022919/\#axzz4HISA0gM6 (accessed 15 January 2017).

58 Renewable Energy Magazine, Spanish Congress Approves Royal Decree Described as 'The Photovoltaic Sector's Ruin', (28 February 2011), http://www.renewableenergymagazine.com/article/spanish-congressapproves-royal-decree-described-as (accessed 15 January 2017).

59 John Parnell, Fight against Spain’s Solar Cuts Taken to Brussels, PV Tech, (23 June 2014), http://www.pvtech.org/news/spanish_solar_cuts_case_taken_to_european_commission (accessed 15 January 2017).

${ }^{60}$ Ministry of Industry and Trade notice 252/2001 coll.
} 
(Act) ${ }^{61}$ introduced a guarantee requiring TSOs/DSOs to purchase all electricity generated from renewable sources for a period of fifteen years, and set up a mechanism whereby producers can choose between a FIT and a FIP. The Act also authorized a regulator to set FIT rates for each year that could not be reduced by more than five percent of the previous years' rates, and were to be differentiated by type of renewable source and by year of commissioning. This legislation significantly increased the tariff available for PV solar installations, reduced the discretion of the energy regulator in adjusting prices, and offered long-term contracts guaranteeing the payment of all electricity produced from PV solar.

Figure 2: Annual Installed PV Solar in the Czech Republic in MWh

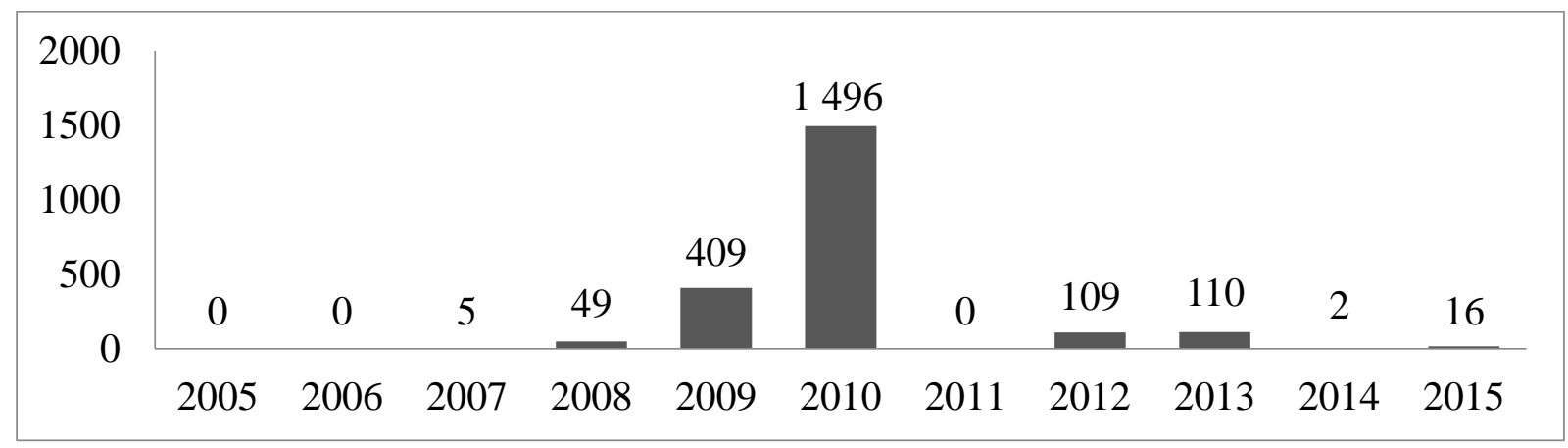

There was a drastic increase in PV solar installations after 2008, indicating that the renewable support scheme was working. ${ }^{62}$ The increase created problems related to the potential costs of the support scheme over the long-term and a high risk of instability to the electricity grid. ${ }^{63}$ This led to a number of reforms and amendments to the Act aimed at reducing the FIT and to claw-back some of the extraordinary profits that were being generated by those PV solar installations that came online before 2011: (1) the introduction of a moratorium on connecting new PV solar installations to the grid in $2011 ;{ }^{64}$ (2) the FIT support for large PV solar installations would be terminated from 1 March $2011 ;^{65}$ (3) a tax holiday granted to producers of electricity from renewable sources was removed; ${ }^{66}$ (4) a gift tax was placed on carbon credits for 2011 and 2012 and a tax of twenty-eight percent on PV solar installations built in 2009 and 2010 that receive the FIT (twenty-six percent on the FIP) was to apply from 2011 through $2013 ;{ }^{67}$ (5) a new regulation permitted the regulator to reduce the annual FIT and FIP

\footnotetext{
${ }^{61}$ Act 180/2005 coll., Act on the promotion of electricity production from renewable energy sources and amending certain acts (Act on Promotion of Use of Renewable Sources), (31 March 2005), http://www.czrea.org/ files/pdf_en/zakony/RES_act_english.pdf (accessed 15 January 2017).

${ }^{62}$ IEA, Energy Policies of IEA Countries: The Czech Republic 2010 Review (2010), at 85, https://www.iea.org/ publications/freepublications/publication/CzechRep2010_free.pdf (accessed 15 January 2017).

${ }^{63}$ Solar plaza, Photovoltaic in the Czech Republic: Status Update (29 March 2011), http://www.solarplaza.com/ channels/archive/11243/photovoltaic-in-the-czech-republic-status-update/ (accessed 15 January 2017); see also Luigi Dusonchet \& Enrico Telaretti, Economic Analysis of Different Supporting Policies for the Production of Electrical Energy by Solar Photovoltaics in Eastern European Union Countries 38 Energy Policy 4013-4014 (2010).

${ }^{64}$ Act 180/2005 coll. amendment of 1 April 2010. On 16 February 2010, the Czech Republic TSO banned the connection of all new PV solar plants to the grid until the end of 2011.

${ }^{65}$ Act 180/2005 coll. amendment, (3 November 2010).

${ }^{66}$ Act 586/1992 coll. amendment, (12 November 2010).

${ }^{67}$ Act 180/2005 coll. amendment, (14 November 2010).
} 
for PV solar installations by more than the previously limited five percent; ${ }^{68}$ and (6) legislation was passed to extend the PV solar tax with an open-ended ten percent tax on all electricity generated and to terminate all renewable energy support schemes for new installations from $2014 .^{69}$

The regime governing the PV solar sector remains fragmented with different support schemes governing projects brought online at different times. For example, in 2015, the Energy Regulatory Office of the Czech Republic (ERO) issued Price Decision Number 5/2015 (concerning the support to renewable energy sources commissioned from 1 January 2013 to 31 December 2015) and Price Decision Number 9/2015 (support to renewable energy sources put into operation before 2013, holding a valid license and financially supported so far) with continuing varied levels of support based on the time the investment was made. ${ }^{70}$ Additionally, the Czech Republic recently launched the Operational Programme Enterprise and Innovation for Competitiveness 2014-2020 (OPPIK) offering investment grants supporting energy efficiency of the business sector and the development of energy from renewable sources - but interestingly excludes PV solar energy. ${ }^{71}$

Like the Spanish situation, this fragmentation and uncertainty has led to a number of lawsuits. At the national level, a case was filed at the Czech Constitutional Court claiming that the PV solar tax was discriminatory and violated the Constitution. In a decision rendered on 15 May 2012, the court upheld the PV solar tax and determined that legal certainty was not an absolute right immune from socio-economic changes. ${ }^{72}$

\section{Italy}

The 2001 and 2009 Directives prompted the creation of the Italian legal framework for support to renewable energy sources. ${ }^{73}$ The promotion of PV solar began in 2005 following the enactment of renewable energy promotion regulations (the first conto energia). PV solar was promoted through green certificates with a monetary value in excess of the market price for electricity. ${ }^{74}$ For PV solar installations, the green certificates amounted to approximately

\footnotetext{
${ }^{68}$ Regulation 2/2010, 18 November 2010. The FIT rates were forty-seven to fifty-five Eurocents/kWh for the years 2007 to 2010, and fell to between eight and twenty-one Eurocents/kWh for 2011 to 2013.

${ }^{69}$ Act 165/2012 coll. on supported energy sources and on amendment to some laws (31 January 2012); Act. 310/2013 coll.; see also CEER, Status Review of Renewable and Energy Efficiency Support Schemes, (2010), 19: Czech Electricity and Gas Market Operator (OTE), Year Report on the Electricity and Gas Market in the Czech Republic for 2013, at http://www.ote-cr.cz/o-spolecnosti/soubory-vyrocni-zprava-ote/rocni-zprava-2013.pdf (accessed 15 January 2017); European Commission, Decision SA.35177(2014/N) - Czech Republic - Promotion of Electricity from Renewable Energy Sources, (11 June 2014).

${ }^{70}$ OTE, Press Release, (4 January 2016), http://www.ote-cr.cz/about-ote/file-news/160105-press-release.pdf (accessed 15 January 2017); Renewables International, Renewables Face Extinction in Czech Republic (16 December 2015), http://www.renewablesinternational.net/renewables-face-extinction-in-czech-republic/150/5 37/92342/ (accessed 15 January 2017).

${ }^{71}$ OPPIK, Eco-energy - Renewables, http://www.oppik.cz/en/subsidy-programmes/eko-energie (accessed 15 January 2017); Ministry of Industry and Trade of the Czech Republic, Operational Programme Enterprise and Innovation for Competitiveness 2014-2020 (April 2015), Target 3.1, http://www.mpo.cz/dokument169167.html (accessed 15 January 2017).

${ }^{72}$ Czech Republic Constitutional Court Judgment, Photovoltaic Power Plants, Pl. US 17/11, (15 May 2012).

${ }^{73}$ Legislative Decree no. 387/03; for further details, see Saverio Massari, The Italian Photovoltaic Sector in Two Practical cases: How to Create an Unfavorable Investment Climate in Renewables, OGEL 3 (2015).

${ }^{74}$ Ministerial decree, (28 July 2005).
} 
forty-five Eurocent/kWh and were granted to producers ${ }^{75}$ under twenty year contracts. These certificates were consequently comparable to FIPs. In two subsequent conto energias, the Italian legislature adjusted various parts of the green certificate scheme. ${ }^{76}$

Figure 3: Annual Installed PV Solar in Italy in MWh

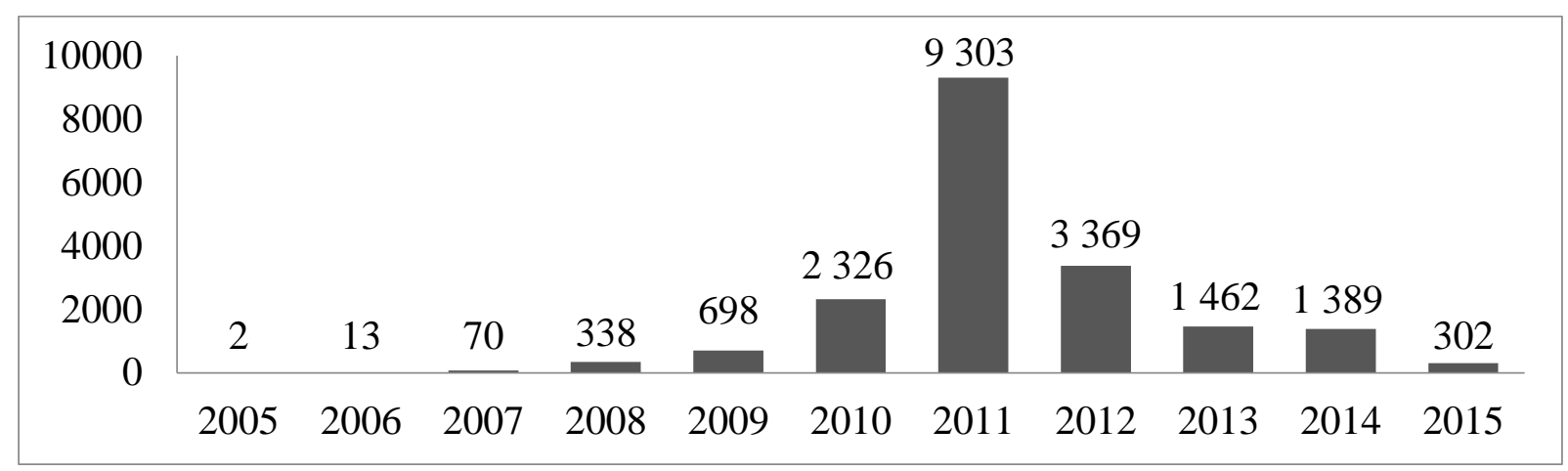

The fourth conto energia significantly changed the structure of renewable support schemes by switching to a fixed price FIT or FIP. ${ }^{77}$ By the time the fourth conto energia came into force, Italy had installed over $10000 \mathrm{MW}$ of PV solar. The dramatic increase in 2010 and 2011 put significant strain on the system. The fourth conto energia aimed at phasing out the green certificate program by 2015 and to implement FIT and FIP rates that could be 'progressively reduced over time, in order to balance the level of public support with the costs of technologies, giving stability and certainty to the market'. ${ }^{78}$ By the end of 2011, the support offered under the fourth conto energia had declined by thirty-one percent compared to the rates offered under the second conto energia. ${ }^{79}$ In 2012, the fifth conto energia modified the support scheme for PV for the fourth time in six years. ${ }^{80}$ The purpose was essentially to terminate the support scheme for utility scale PV solar installations and to put a new cap on annual spending. ${ }^{81}$

The support scheme for PV solar in Italy comes directly out of the state coffers. This is distinct from the approach taken in Spain and the Czech Republic where PV solar support is paid by the TSO/DSO and the additional cost (at least partly) is passed onto the customer. The fifth conto energia sets a cap for total support at 6.7 billion Euro per year. In 2013, the cap was reached in June. ${ }^{82}$ Given that the majority of twenty year support contracts for green

\footnotetext{
${ }^{75}$ See Gestore Servizi Energetici (GSE), Green Certificates, http://www.gse.it/en/qualificationandcertificates/ Pages/default.aspx (accessed 15 January 2017).

${ }^{76}$ Ministerial decree, (19 February 2007); Ministerial decree, (6 August 2010).

${ }^{77}$ Ministerial decree, (5 May 2011).

${ }^{78}$ GSE, Fourth Feed-in-Scheme, http://www.gse.it/en/feedintariff/Photovoltaic/Fourth\%20feed-in\%20tariff/ Pages/default.aspx (accessed 15 January 2017).

${ }^{79}$ del Rio \& Mir-Artiques, A Cautionary Tale, supra n 50, 58.

${ }^{80}$ Ministerial decree, (5 July 2012).

81 GSE, Fifth Feed-in-Scheme, http://www.gse.it/en/feedintariff/Photovoltaic/FifthFeed-inScheme/Pages/ default.aspx (accessed 15 January 2017).

${ }^{82}$ Carsten Steinhauer \& Riccardo Narducci, Italy: Euro 6.7 Billion Cap for Photovoltaic Incentives Reached, Energy Business Law (7 June 2013), http:/www.energybusinesslaw.com/2013/06/articles/eu-developments/ italy-euro-6-7-billion-cap-for-photovoltaic-incentives-reached (accessed 15 January 2017).
} 
certificates date from about 2010, the available support has already been spent through approximately 2030. The result is that very few new PV solar installations will receive any support. The fifth conto added a controversial local content bonus of two Eurocents $/ \mathrm{kWh}$ that is available to PV solar producers if a certain percentage of the solar panels are sourced from within the EU. ${ }^{83}$

In mid-2014, the Italian legislature intervened on an emergency basis. ${ }^{84}$ This intervention reduced all previous support price guarantees for PV solar by seventeen to twenty-five percent with effect from 1 January 2015. Finally, on 30 June 2016, a new Ministerial decree providing incentives to electricity production from renewable energy sources other than PV solar entered into force. ${ }^{85}$ According to Italy, PV solar energy is already competitive on the market and does not require additional support. ${ }^{86}$ Although PV solar is explicitly excluded, Art. 29 of the new decree might provide for the inclusion of PV solar energy, which could possibly expose the GSE to legal liability if it decides to reduce or revoke previously granted incentives relating to PV solar installations. ${ }^{87}$

\section{Concluding Remarks}

These case studies were chosen because of the problems that occurred in implementing support schemes for the promotion of renewable energy among EU Member States. There are two major sets of conditions that the three case study states failed to anticipate: one is external and one is internal. The external conditions are the global financial recession and the unanticipated decline in the cost of solar panels. These changes restricted the amount of financial support that could be allocated for the promotion of renewable technologies when approaching 2010, and the decline in the price of PV solar panels meant that there would be a surge of investment in the sector due to the windfall profits that high tariffs and low production costs would generate.

While the external conditions were unanticipated, the internal condition was highly predictable and could have largely been avoided. In all three of the case studies, but to varying degrees, the regulatory structure established to implement the support schemes for PV solar were inflexible and unable to quickly respond to changing market conditions. In all three cases, PV solar was over-incentivized initially. By the time that regulators and legislators realized that the FITs and FIPs were unsustainable, it was too late and drastic emergency-type measures were required to control new investment in the sector. Such measures have reduced future subsidies and clawed back some of the 'wind-fall profit' of investors, and they have resulted in very significant reduction in the establishment of PV solar production capacity.

\footnotetext{
${ }^{83}$ This local content requirement is being challenged by China before the WTO Dispute Settlement Mechanism (DSM) in: European Union and Certain Member States - Certain Measures Affecting the Renewable Energy Generation Sector (Complainant: China), DS 452, in consultations (5 November 2012).

${ }^{84}$ Law decree 91/2014, (25 June 2014).

${ }^{85}$ Ministerial decree, (23 June 2016).

${ }^{86}$ This new Italian support scheme for renewable energy generation was found to be in line with the Community Guidelines on State Aid for Environmental Protection and Energy 2014-2020 (2014 Guidelines). See European Commission, State Aid SA.43756 - Support to Electricity from Renewable Sources Italy (28 April 2016).

${ }^{87}$ Carsten Steinhauer \& Riccardo Narducci, Italy: New Incentives for Renewable Energy Plants (1 July 2016), https://www.mwe.com/en/thought-leadership/publications/2016/07/italy-new-incentives-for-renewable-energyplants (accessed 15 January 2017).
} 
The latter is remarkable since the falling costs of PV solar should rather have led to an increase in installed capacity.

The measures taken by the Member States have drawn criticism from the Commission. In its 2013 report on progress under the 2009 Directive, it stated that:

... rigid national support schemes were generally unable to adapt rapidly enough to ... falling costs, raising profits and creating a rate and scale of installations in some countries almost excessive in a time of general economic crisis. The result has been sudden and unpredictable changes to a number of national support schemes, which will, again, curtail investment such that there remains a risk that the current surplus of PV over planned levels (46TWh rather than 35TWh) will disappear and become a deficit by 2020 ...

Given the prominent role that financial support schemes play in developing renewable energy today, and given the growing prominence (and cost) of renewable energy use in the electricity sector, urgent efforts are needed to reform support schemes to ensure that they are designed in a cost effective, market-oriented manner. The Commission's guidance is necessary to ensure that support schemes are adjusted regularly and quickly enough to take account of falling technology costs and to ensure reforms make renewable energy producers part of the energy market (such as by moving from feed in tariffs to feed in premiums or quotas, and using tendering to avoid over compensation etc.); to ensure such market interventions are correcting market failures and not adding or maintaining market distortions ...

Many national reforms have had a negative impact on the investment climate. Most critical have been changes that reduce the return on investments already made. Such changes alter the legitimate expectations of business and clearly discourage investment, at a time when significantly more investment is needed. ${ }^{88}$

\section{Scaling Back Incentives and the Investment Treaty Problem}

Investors that are unhappy with the plans to scale back support schemes can resort to dispute settlement under IIAs. Rules that discourage support on the one hand, and rules that provide remedies if they are withdrawn or modified, on the other, could cause significant tensions between a modified EU regime on the promotion of renewable energy and the international regime on the protection of foreign investment. While the practice to date indicates that there has been little overlap, a recent influx of investment cases may change this perception.

As was seen in the case studies, the subsidization of renewable energy production through FIT programs resulted in rapid and unsustainable growth. To respond to this growth, all three states have had to scale back the incentives; and it is this process of modifying and withdrawing certain benefits that has led to a significant number of international legal

\footnotetext{
${ }^{88}$ See European Commission, Report from the Commission to the European Parliament, the Council, the European Economic and Social Committee and the Committee of the Regions: Renewable energy progress report, $\operatorname{COM(2013)~175,~5,~} 9$ (27 March 2013), http://eur-lex.europa.eu/legal-content/EN/TXT/PDF/?uri= CELEX:52013DC0175\&from=EN (accessed 15 January 2017).
} 
disputes. Foreign investors are challenging measures that have the effect of reducing the profitability of certain renewable energy projects. Since the attempts to seek recourse in the domestic courts of the Czech Republic, Spain and Italy by aggrieved PV solar investors have not been fruitful, foreign investors have initiated at least forty-seven international investment treaty arbitrations based on the ECT. ${ }^{89}$ There have been thirty-three cases brought against Spain (two have been decided), ${ }^{90}$ seven cases against the Czech Republic and seven cases against Italy.

Similar to other IIAs, the ECT provides a standing offer to foreign investors to initiate arbitration against host states claiming that they have violated the ECT. Investors can bring claims in three ways: (1) arbitration through the International Centre for Settlement of Investment Disputes (ICSID), (2) ad hoc arbitration according to the UNCITRAL arbitration rules, or (3) arbitration hosted by the Stockholm Chamber of Commerce (SCC) (ECT, Art. 26). Of the forty-seven cases filed to date, thirty-three are ICSID arbitrations, nine are ad hoc UNCITRAL arbitrations, and five are SCC arbitrations.

Considering that most of these cases are still pending and that there is no default rule requiring that the registration of the cases or that awards be made publicly available, it is unknown exactly how many cases exist and on what legal basis most of the claims are being made. In the case of Spain, all thirty-three of the cases have been brought by investors from Western Europe.

The timing of the cases may give an indication as to which measures are being challenged. For example, the first of these cases against Spain is an ad hoc UNCITRAL arbitration brought in November of 2011 by a consolidated group of investors in the Spanish PV solar sector. $^{91}$ It is likely that this claim is based on the changes made to the FIT program in 2010. As was seen in section III(A), two laws passed in 2010 reduced the duration under which the FIT would be available, put a limit on the number hours that PV solar could benefit from the FIT, and added a new grid access fee. ${ }^{92}$ The claimants will have to show that these changes amounted to an indirect expropriation of their investment (Art. 13, ECT) or violated the fair and equitable treatment (FET) obligation (Art. 10, ECT).

The other thirty-two cases against Spain have been filed over a relatively long time period ranging from the first cases in 2013 up through the latest in August 2016. ${ }^{93}$ Four of the cases are SCC arbitrations ${ }^{94}$ and twenty-eight are ICSID arbitrations. ${ }^{95}$ These cases could be based

\footnotetext{
${ }^{89}$ Two of the cases also refer to a bilateral investment treaty (BIT) in addition to the ECT.

${ }^{90}$ While the majority of the cases are in relation to PV solar projects, ten of the cases arise out of CSP projects. However, the legislative changes to the FIT program that are being challenged in these cases applied to both PV solar and CSP projects.

${ }^{91}$ PV Investors v Spain (UNCITRAL), ECT (1 November 2011). PV Investors is a group of the following 16 investors: AES (France), Ampere (Netherlands), Element (UK), Eoxis (UK), European Energy (Denmark), Foresight (UK), GreenPower (Denmark), GWMLux (Luxembourg), HgCapital (Germany), Hudson (UK), Impax (UK), KGAL (Germany), NIBC (Belgium), Scan (Denmark) and White Owl (Germany).

${ }^{92}$ See supra n $47,48$.

${ }^{93}$ Date references in all pending cases provide the known date of case registration.

${ }^{94}$ Charanne (Netherlands) v Spain (SCC), ECT (2013); Isolux (Netherlands) v Spain (SCC), ECT (2013); CSP Equity Investment SARL (Luxembourg) v Spain (SCC), ECT (2013); Alten Renewable Energy Developments (Netherlands) BV v. Spain (SCC), ECT (2015).

${ }^{95}$ RREEF (UK) v. Spain (ICSID Case No. ARB/13/30), ECT (22 November 2013); Antin (France) v Spain (ICSID Case No. ARB/13/31), ECT (11 November 2013); Eiser (UK) v Spain (ICSID Case No. ARB/13/36),
} 
on the legislative changes of 2010, but they may also be tied to the changes occurring in 2013 and 2014: the mandated reduction in the internal rate of return of PV solar projects to approximately five percent and the seven percent tax on all electricity generated. ${ }^{96}$

In the last six months, two Spanish cases have reached Awards. The first arbitral Award rendered in relation to Spain's changes to its FIT program for PV solar came in early 2016. ${ }^{97}$ The claims in this case were limited to legislative changes through 2010. In an Award dated 21 January 2016, the Tribunal dismissed the entirety of the claimants' claims. Although the 2010 modifications to the FIT program had a significant impact on the profitability of PV solar projects, they were not of a severity amounting to a breach of the investment protection standards in the ECT. It should be noted that the Award rendered by this Tribunal is not binding on any future Tribunals, and therefore may make predictions as to outcome difficult to assess, especially in the other Spanish disputes relating to the more severe legislative changes that occurred in 2013 and 2014; or the other disputes against the Czech Republic and Italy. 98

However, in what might become a trend, a second Award was rendered in July $2016 .{ }^{99}$ In this case, the Tribunal likewise dismissed the claimant's claims in their entirety. What is even more interesting is that this case included later legislative changes to the PV solar sector in Spain (i.e. those occurring in 2013 and 2014). These later changes were so severe as to make the investor's investments completely unprofitable; and yet the Tribunal determined that these changes did not violate the relevant provisions in the ECT. More and more of these cases will be decided in the next year - and at least in terms of the Spanish context, it is now increasingly likely that many of these claims will fail. From a policy perspective, it may be that these arbitrations acted as a wakeup call for many Member State regulators, but that in

ECT (23 December 2013); Masdar (Netherlands) v Spain (ICSID Case No. ARB/14/01), ECT (11 February 2014); NextEra (Netherlands) v Spain (ICSID Case No. ARB/14/11) ECT (23 May 2014); InfraRed (UK) v Spain (ICSID Case No. ARB/14/12), ECT (3 June 2014); Renergy (Luxembourg) v Spain (ICSID Case ARB/14/18), ECT (1 August 2014); RWE (Germany) v Spain (ICSID Case No. ARB/14/34), ECT (23 December 2014); Stadtwerke (Germany) v Spain (ICSID Case No. ARB/15/1), ECT (7 January 2015); STEAG (Germany) v Spain (ICSID Case No. ARB/15/4), ECT (21 January 2015); 9REN (Italy) $v$ Spain (ICSID Case No. ARB/15/15), ECT (21 April 2015); BayWa r.e. (Germany) v Spain (ICSID Case No. ARB/15/16), ECT (8 May 2015); Cube Infrastructure (Luxembourg) v Spain (ICSID Case No. ARB/15/20), ECT (1 June 2015); Mathias Kruck (Germany) v Spain (ICSID Case No. ARB/15/23), ECT (6 June 2015); KS Invest \& TLS Invest (Germany) $v$ Spain (ICSID Case No. ARB/15/25), ECT (16 June 2015); JGC (UK) v Spain (ICSID Case No. ARB/15/27), ECT (22 June 2015); Cavalum (Portugal) v Spain (ICSID Case No. ARB/15/34), ECT (4 August 2015); E.ON (Germany) v Spain (ICSID Case No. ARB/15/35), ECT (10 August 2015); OperaFund (Malta) v Spain (ICSID Case No. ARB/15/36), ECT (11 August 2015); SoIEs (Germany) v Spain, (ICSID Case No. ARB/15/38), ECT (24 August 2015); Hydro Energy (Luxembourg) v Spain (ICSID Case No. ARB/15/42), ECT (19 October 2015); Watkins (Luxembourg) v Spain (ICSID Case No. ARB/15/44), ECT (4 November 2015); Landesbank (Germany) $v$ Spain (ICSID Case No. ARB/15/45), ECT (12 November 2015); Eurus (Netherlands) v Spain (ICSID Case No. ARB/16/4), ECT (1 March 2016); Sun-Flower Olmeda (Germany) v Spain (ICSID Case No. ARB/16/17), ECT (28 June 2016); Infracapital (Luxembourg) v Spain (ICSID Case No. ARB/16/18, ECT (29 June 2016); Sevilla Beheer (Netherlands) v Spain (ICSID Case No. ARB/16/27), ECT (12 August 2016).

${ }^{96}$ See supra n 52-55.

${ }^{97}$ Charanne (Netherlands) v Spain (SCC), ECT, Award (21 January 2016).

${ }^{98}$ Daniel Behn, Spain Wins First PV Solar Arbitration: A Word of Caution in Using this Case to Predict Outcome in the Three Dozen Cases to Come, PluriCourts Blog, (27 January 2016), http://www.jus.uio.no/ pluricourts/english/blog/daniel-friedrich-behn/2016-01-26-arbitration-spain.html (accessed 15 January 2017).

${ }^{99}$ Isolux (Netherlands) v Spain (SCC), ECT, Award (13 July 2016). 
the end, these states (at least Spain) may emerge relatively unscathed. Only the future will be able to tell whether the lessons learned from this ordeal assist in shaping better regulatory regimes for the promotion of renewable energy going forward.

In addition to the Spanish cases, there are seven cases that were filed against the Czech Republic in 2013. All cases are being brought by claimants from Western Europe and all are UNCITRAL arbitrations. ${ }^{100}$ These cases are likely to be based on claims of indirect expropriation and violations of the FET standard as they probably relate to tax adopted in 2012 that only applies to PV solar projects installed in 2009 and 2010. ${ }^{101}$

One case was filed against Italy in late 2013, four cases in 2015 and two cases in 2016. Six of the cases are ICSID arbitrations ${ }^{102}$ and one is a SCC arbitration. ${ }^{103}$ The claims in this case are also likely to be based on indirect expropriation and the FET standard. The timing of the 2013 case indicates that the challenged measure may be the cap on annual spending added under the fifth conto energia or administrative changes that rendered a particular PV solar project unprofitable. ${ }^{104}$ However, more recent legislative changes introduced by the Italian parliament in June 2014 may give rise to a larger number of new investment treaty claims because it reduces the price guarantees given to PV solar producers and could be viewed as a violation of the legitimate expectations of PV solar investors under the ECT. ${ }^{105}$

One other major question that arises in these cases is whether and how the investment tribunals will take into account states' duties under GATT, ${ }^{106}$ the SCM Agreement ${ }^{107}$ and the Treaty on the Functioning of the European Union (TFEU) to discipline the use of subsidies. The respondent states are likely to argue that the contested measures are justified as means of implementing their obligations under these treaties. If such arguments turn out to be unsuccessful, states may be mandated by investment tribunals to compensate investors in direct violation of their duties to control trade distorting subsidies. ${ }^{108}$ Moreover, funds that could otherwise have been available as lawful subsidies to assist establishment of new

\footnotetext{
${ }^{100}$ Of the seven cases filed, six are ad hoc UNICTRAL cases, and one case is registered at the Permanent Court of Arbitration (PCA): Antaris (Germany) v Czech Republic (PCA UNCITRAL), ECT (8 May 2013); Natland (Netherlands) v Czech Republic (UNCITRAL), ECT (8 May 2013); Voltaic (Germany) v Czech Republic (UNCITRAL), ECT (8 May 2013); ICW (UK) v Czech Republic (UNCITRAL) ECT (8 May 2013); Photovoltaic (Germany) v Czech Republic (UNCITRAL), ECT (8 May 2013); WA (Cyprus) v Czech Republic (UNCITRAL), ECT (8 May 2013); JSW Solar (Germany) v Czech Republic (UNCITRAL), ECT (1 June 2013).

${ }^{101}$ See supra $\mathrm{n} 69$.

${ }^{102}$ Blusun (Belgium) v Italy (ICSID Case No. ARB/14/3), ECT (21 February 2014); Silver Ridge Power (Netherlands) v Italy (ICSID Case No. ARB/15/37), ECT, (11 August 2015); Belenergia (Luxembourg) v Italy (ICSID Case No. ARB/15/40), ECT (22 September 2015); Eskosol v Italy (ICSID Case No. ARB/15/50), ECT (22 December 2015); ESPF v Italy (ICSID Case No. ARB/16/5), ECT (8 March 2016); VC Holding v Italy (ICSID Case No. ARB/16/39), ECT (6 December 2016).

${ }^{103}$ Greentech Energy (Denmark) v Italy (SCC), ECT (7 July 2015).

${ }^{104}$ See supra n 82-83.

${ }^{105}$ See supra n 81.

${ }^{106}$ General Agreement on Tariffs and Trade 1994 (GATT 1994), 15 April 1994, Marrakesh Agreement Establishing the World Trade Organization, 1867 UNTS 187 (1999).

${ }_{107}$ Agreement on Subsidies and Countervailing Measures (SCM Agreement), 15 April 1994, Marrakesh Agreement Establishing the World Trade Organization, 1869 UNTS 14 (1999).

${ }^{108}$ See the European Commission's decision of 1 October 2014 to initiate the formal investigation procedure: (SA.38517): Romania Implementation of Arbitral Award Micula v Romania of 11 December 2013, OJ C 393/03, 27-40 (7 November 2014).
} 
production of renewable energy could be channeled towards securing an excessively high return on existing production facilities as a result of such decisions. In line with this type of reasoning, the Commission has sought leave to intervene in the PV solar cases against the Czech Republic claiming, inter alia, that the state aid offered to investors in the Czech Republic to support their PV solar projects was never notified to the Commission and therefore never constituted permissible state aid according to EU law. ${ }^{109}$ The Commission is implying that any award against the Czech Republic in these cases would itself be illegal state aid and therefore unenforceable. ${ }^{110}$

While the outcome of these cases will be closely monitored by those who have invested in renewable energy technologies under various support schemes throughout the world, these cases also have a special importance in the European context. All of the cases brought to date are intra-EU disputes. In previous intra-EU investment treaty disputes, the Commission has stated that investment tribunals do not have jurisdiction over cases between EU Member States because only the EU has competence to rule on issues of EU law. ${ }^{111}$ However, the Tribunal in Charanne found that there is no legal obstacle preventing European investors from bringing ECT claims against EU Member States. ${ }^{112}$ The PV solar cases are likely to intensify the exchange between the Commission and investment treaty tribunals constituted under the ECT or intra-EU BITs. ${ }^{113}$ It is likely that the cases will contribute to a major shift in policy and practice of the EU and its Member States in regards to investment treaty arbitration. It is also likely that the CJEU will become involved. ${ }^{114}$ The strength and dedication with which investors have pursued their rights in investment tribunals, as well as the numerous cases before domestic courts, illustrate the importance of the interests involved. Such cases are resource demanding, and investors are likely to use such avenues only as a

\footnotetext{
${ }^{109}$ IA Reporter, Brussels' Latest Intervention Casts Shadow over Investment Treaty Arbitrations Brought by Jilted Solar Energy Investors (8 September 2014), http://www.iareporter.com/articles/20140908_3 (accessed 15 January 2017).

${ }^{110}$ See Micula v Romania (ICSID Case ARB/05/20), BIT, Award (11 December 2013) where the Commission has successfully prevented Romania from satisfying an ICSID award rendered against it on the grounds that enforcement of the award would be akin to illegal state aid.

${ }^{111}$ See e.g. Electrabel v Hungary (ICSID Case ARB/07/19), ECT, Award (25 November 2015); EDF v Hungary (UNCITRAL), ECT, Award (4 December 2014); Micula, ibid; US Steel $v$ Slovakia (PCA UNCITRAL), Discontinued. In Electrabel and EDF, the Commission intervened as a non-disputing party claiming that the tribunal did not have jurisdiction over claims relating to EU law. In Micula and US Steel, the Commission intervened as a non-disputing party claiming that any award rendered against Romania and Slovakia, respectively, would be equivalent to illegal state aid. After an award was rendered against Romania in 2013 in the Micula case, the Commission enjoined Romania from paying the ICSID award. The Micula brothers brought a case against the Commission before the CJEU to have the injunction quashed, Case T-646/14, Micula and Others v Commission (2014). In US Steel, the claimants dropped the case after doubts about its eventual enforceability were made by the Commission in its submissions.

${ }^{112}$ Charanne (Netherlands) v Spain (SCC), ECT, Award (21 January 2016), §§ 424-450; see also RREEF (UK) v Spain (ICSID Case No. ARB/13/30), ECT, Award on Jurisdiction (6 June 2016), §§ 71-90.

113 The Commission has sought leave to file interventions in six of the seven cases against the Czech Republic and in nine of the thirty-three cases against Spain. IA Reporter European Commission Wades into Solar Arbitrations against Spain, Intervening in One Case a Week before Final Hearings (17 November 2014), https://www.iareporter.com/articles/european-commission-wades-into-solar-arbitrations-against-spainintervening-in-one-case-a-week-before-final-hearings/ (accessed 15 January 2017).

114 See CJEU T-646/14, Micula and Others v Commission (26 February 2016 ): the Court ordered to remove from the register the application for annulment of Commission decision C (2014) 3192 of 26 May 2014.
} 
measure of last resort. However, it remains to be seen whether investors will follow through or abandon the cases before they are resolved.

\section{The 'Europeanization’ of Renewable Policy - Remedies to Address Market Distortions}

The last decade has witnessed increasing tensions between the European internal market in electricity and national support schemes. In fact, most preferential national treatment schemes at the Member State level are likely to be in contradiction with the economic freedoms at the heart of the internal Energy market. ${ }^{115}$ These tensions relate specifically: (1) to the level of control that the EU can exert on its Member States in regard to the design of their national support schemes for the promotion of renewable energy, and (2) to the functioning of the single energy market when support schemes for the promotion of renewable energy are designed, implemented, and largely restricted to energy produced within a specific Member State. To overcome some of the problems of cross-border 'leakage' and of market distortions arising from uncoordinated support schemes among Member States, the 'guidance' offered by the Commission would entail an increasing 'Europeanization' of renewable energy promotion policies.

The 2009 Directive did not include a harmonized support mechanism but rather opted for the facilitation of cross-border support of energy (statistical transfer between member states, joint projects and support schemes). ${ }^{116}$ However, this type of cooperation has been under-utilized to date. Member States seem to have relied on their national renewable sources and their capacity to reach their national targets on their own rather than resorting to these joint mechanisms as provided by the 2009 Directive. ${ }^{117}$ One main reason is likely their interest in developing domestic production capacity in renewable energy sectors. A major exception to this national focus has been the cooperation between Norway and Sweden establishing a joint system of green certificates in 2012. ${ }^{118}$ Under this joint system, producers situated in both states can be granted green certificates, electricity suppliers in both states are required to buy a certain quota of energy from renewable energy and can do so in either state. ${ }^{119}$ The aim is

\footnotetext{
115 Sirja-Leena Penttinen, The Role of the Court of Justice of the European Union in the Energy Market Liberalization, in Kim Talus (ed.), Research Handbook on International Energy Law, 262-263 (Cheltenham: Edward Elgar 2014).

${ }^{116}$ Case C-66/13, Green Network SpA, § 64 (2014); see also European Commission, The Support of Energy from Renewable Energy Sources, COM (2005), 627, 11 (7 December 2005); European Commission, The Support of Energy from Renewable Energy Sources, Accompanying document to the proposal for a directive of the European Parliament and the Council on the promotion of the use of energy from renewable sources, SEC (2008) 0057, 13-14 (23 January 2008).

${ }^{117}$ European Commission, Review of European and National Financing of Renewable Energy in accordance with Article 23(7) of Directive 2009/28/EC, SEC (2011) 131, 7, (31 January 2011), http://eurlex.europa.eu/legal-content/EN/TXT/PDF/?uri=CELEX:52011SC0131\&from=EN (accessed 15 January 2017) .

${ }^{118}$ Directive 2009/28/EC, Art. 11. The 2009 Directive was incorporated into the European Economic Agreement (EEA) making Norway subject to the same rights and obligations as provided under the 2009 Directive (Decision of the EEA joint Committee 162/2011 of 19 December 2011 amending Annex IV (Energy) to the EEA Agreement OJ L 76, (15/03/2012)).

${ }^{119}$ Swedish Energy Agency (Energimyndigheten) and the Norwegian Water Resources and Energy Directorate (NVE), The Swedish-Norwegian Electricity Certificate Market: Annual Report 2012, http://www.nve.no/Global/ Elsertifikater/Elcertifikat2013_Eng_TA\%20(2).pdf (accessed 15 January 2017); Energimyndigheten and NVE, Agreement on a Common Market for Electricity Certificates, https://www.regjeringen.no/en/topics/energy/ fornybar-energi/electricity-certificates/id517462/ (accessed 15 January 2017).
} 
for renewable energy investments to be made in optimal locations regardless of national borders.

While the example of cross-border coordination of support schemes highlights the possibility for the implementation of specific policies that reduce problems of 'leakage', they may not be very helpful in determining how a harmonized EU-wide policy on the design of support schemes might work. Much of the problem relating to the 'Europeanization' of support schemes is embedded in the EU's wider policy on permissible state aid. To specifically address problems highlighted in our case studies, the Commission is modifying (restricting) its approach to state aid in relation to renewable energy support schemes. In its most recent 2014 Guidelines, ${ }^{120}$ the Commission has broadened the scope of the guidelines to specifically deal with support for renewable energy projects. At the same time, the new guidelines seek to move state aid rules in line with the liberalization of the electricity market and seek 'more market oriented approaches that reflect the evolving cost structure of energy technologies and increasing cost competitiveness in the internal market'. ${ }^{121}$ In accordance with these guidelines, state aid in the support of renewable energy generation - from 2017 onwards will be permissible when granted in a competitive bidding process as a premium increasing cost effectiveness, limiting distortions of competition and exposing renewables to market signals, except for certain installations with a smaller installed electricity capacity. ${ }^{122}$ Such a change in permissible state aid is a dramatic turn from the type of state aid that has been permissible to date. Some Member States have already started reforming their support schemes in line with the 2014 Guidelines. ${ }^{123}$

Concerned that the 2014 Guidelines will reduce the ability of Member States to support the development of their renewable energy plans, the European Renewable Energies Federation (EREF) initiated annulment proceedings against the chapter on operating aid for renewable energy sources of the 2014 Guidelines. ${ }^{124}$ In support of its action, EREF claimed that: (1) the Commission lacked competence to adopt the guidelines citing Article 194 of the TFEU and claiming that technology-neutral renewable energy support schemes cannot be imposed on the Member States as they impact their sovereign energy rights; ${ }^{125}$ (2) the Commission did not provide sufficient justifications for the adoption of a policy requiring all Member States to adopt a technology-neutral competitive binding system to support renewable energy; (3) the Commission infringed the principle of proportionality as the instruments proposed in the guidelines are not suitable for the objectives of promoting renewables in the EU while reducing distortive effects; and (4) the Commission misused its power in trying to legislate on the harmonization of renewable energy support schemes, an area where even the EU legislator

\footnotetext{
120 European Commission, Communication from the Commission, Community Guidelines on State Aid for Environmental Protection 2014-2020, OJ C 200, § 11 (28 June 2014), http://eur-lex.europa.eu/legalcontent/EN/TXT/?uri=CELEX:52014XC0628(01) (accessed 15 January 2017).

${ }^{121}$ European Commission, A Policy Framework for Climate and Energy, supra n 21, 9, European Commission, Community Guidelines on State Aid, ibid, § 11.

122 European Commission, Community Guidelines on State Aid, ibid, §§ 124-130.

${ }^{123}$ See e.g. supra $\mathrm{n} 86$.

${ }^{124}$ Case T-694/14, EREF v Commission (2015).

${ }^{125}$ Case T-694/14, EREF v Commission, Application, (22 September 2014). The EREF has additionally claimed that the Commission cannot use guidelines to adopt 'quasi legislation' to go against the provisions of EU secondary law, i.e. the 2009 Directive which does not attempt to harmonize support schemes but leaves Member States with flexibility and control to develop such schemes.
} 
is not competent. The CJEU held on 23 November 2015 that the claim was inadmissible on the ground that the applicant was not directly affected by the contested guideline. ${ }^{126}$

Confronted with conflicting objectives (national support schemes and the protection of free movement), the CJEU, a central institution for the interpretation of EU Law, was required to clarify the scope of national support schemes for the promotion of renewable energy. One question raised in its existing case law is whether national support schemes can discriminate against producers from other Member States and whether this can result in an unjustifiable barrier to trade.

More recently, in the Ålands Vindkraft case, the CJEU was required to assess the denial by the Swedish Energy Agency to award green certificates to the Finish company, Ålands Vindkraft, operating a wind farm located on the Åland archipelago in Finland. The CJEU indicated that the Swedish certificates system was adopted in an effort to achieve the national renewable energy targets, as provided by in the 2009 Directive. In accordance with its earlier case law, the CJEU found that the 2009 Directive grants Member States the right to decide 'to which extent they support energy from renewable sources which is produced in a different Member State'. ${ }^{127}$ The green certificate scheme is therefore not intended to be extended to producers on the territory of another Member State. ${ }^{128}$ The CJEU concluded that the measure constituted a measure similar to a quantitative restriction (Art. 34, TFEU), but ruled that the Swedish system was justified on the ground of the protection of the environment by promoting renewable energy (public interest ground as listed in Art. 36 TFEU). ${ }^{129}$

The CJEU assessed the Swedish certification scheme in light of the proportionality principle $^{130}$ and explained the three main reasons for the justifications of the territorial limitation in the Swedish support scheme. First, the CJEU adopted the view 'that national support schemes are designed to favor energy at the production stage rather than at the consumption stage as environmental objectives can mainly be achieved at the production stage'. ${ }^{131}$ Second, Member States should be able 'to control the effect and costs of their national support schemes according to their different potentials, while maintaining investor confidence'. ${ }^{132}$ The CJEU emphasized that 'EU law has not harmonized the national support schemes for green electricity' and therefore Member States should in principle be entitled to include territorial limitations in their national schemes. ${ }^{133}$ Third, the Swedish territorial limitation is still necessary even though Sweden has already reached its target, as it can support investment in new installations, give producers certain guarantees about the future of green electricity and thereby protect investor confidence.

Ultimately, the CJEU ruled that Member States do not need to open their renewable energy support schemes to energy producers in other Member States. The reasoning of the CJEU in this case focused on the efficiency of the actual national support schemes system and its

\footnotetext{
${ }^{126}$ For more information on the competence of the Commission regarding legislations on renewable energy, see Peeters, supra n 14.

${ }^{127}$ Case C-573/12, Ålands Vindkraft §52 (2014); see also Case-379/98, Preussen Elektra (2001).

${ }^{128}$ Ibid., §§ 52-53.

${ }^{129}$ Ibid., §§ 78-80 referring to Case-379/98, Preussen Elektra (2001).

${ }^{130}$ Ibid., § 83.

${ }^{131}$ Ibid., § 95

${ }^{132}$ Ibid., § 99

${ }^{133} \mathrm{Ibid}$., § 94
} 
territorial restrictions to secure investor confidence and thereby promote the renewable energy produced by each Member State. It seems however that the CJEU failed to address in its proportionality assessment why territorial restrictions in national support schemes are necessary to achieve the objective of environmental protection.

Similar conclusions were reached in subsequent case law that relates to the 2001 Directive. In the Essent Belgium case, ${ }^{134}$ the CJEU confirmed that the national support schemes were not intended to cover green electricity produced in another Member State. ${ }^{135}$ The CJEU highlighted the role of national support schemes in assisting Member States in achieving their national renewable energy targets and that in doing so they are not required to 'recognise the purchase of a guarantee of origin from other Member States or the corresponding purchase of electricity as a contribution to the fulfilment of a national quota obligation'. ${ }^{136}$ The CJEU referred to the reasoning in the Alands Vindkraft case. ${ }^{137}$ In Ålands Vindkraft and Essent Belgium, the CJEU dismissed the Opinion of the AG Bot who concluded in both cases that the existing EU renewables scheme is contrary to the EU free movement rules and therefore cannot be justified. ${ }^{138}$

Finally, in a similar case, and ruling on the same basis as the previously mentioned cases, the CJEU held, in Green Network, that Italian authorities were not entitled to enact national legislation allowing for the extension of the use of guarantees of origin to green electricity coming from a third state (in this particular case, Switzerland). National support schemes must in principle lead to an increase in the national production of green electricity. ${ }^{139}$

In light of the above, it is apparent that - according to its current design and implementation renewable energy policies and national support schemes are decidedly Member State focused; and that the policies embedded in the 2001 and 2009 Directives will allow Member States to design support schemes in favor of domestic production of renewable energy. In all three rulings briefly described, the CJEU gave great deference to the role of EU Parliament (as reflected in the 2001 and 2009 Directives) by confirming that only the EU Parliament is empowered to decide on the opening of national support schemes to other Member States. ${ }^{140}$ Given these recent decisions, and in light of Member State concerns about the proposed reduction in permissible state aid for the support of renewable energy, the Commission's goal of a 'Europeanization' of renewable energy support schemes could meet significant resistance among Member States. ${ }^{141}$ The potential risks and the political sensitivities of further integrating support schemes on a EU-wide level were highlighted by many respondents to the

\footnotetext{
${ }^{134}$ Case C-204-208/12, Essent Belgium NV (2014).

${ }^{135}$ Ibid., §§ 61-66 referring to Case C-573/12, Ålands Vindkraft (2014).

${ }^{136}$ Ibid., § 68.

${ }^{137}$ See also Henrik Bjørnebye, Joined Cases C-204/12 to C-208/12 Essent Belgium, OGEL 3 (2015).

138 Opinion of AG Bot to the Court in joined Case C-2014/12 to C-208/12, Essent Belgium, EU:C:2013:294 (8 May 2003); Opinion of AG Bot in the Case C-573/12, Alands Vindkraft, EU:C:2014:37 (28 January 2014).

${ }^{139}$ Essent Belgium, supra n 133, §§ 67-68; Green Network, supra n 10, § 57.

${ }^{140}$ Marek Szydlo, How to Reconcile National Support for Renewable Energy with Internal Market Obligations? The Task for the EU Legislature after Ålands Vindkraft and Essent 52(2) Common Market Law Review 489, 509-510 (2015).

${ }^{141}$ Etienne Durand \& Malcolm Keay, National Support for Renewable Electricity and the Single Market in Europe: The Ålands Vindkraft Case, Oxford Energy Comment, Oxford Institute for Energy Studies, (2014), http://www.oxfordenergy.org/wpcms/wp-content/uploads/2014/08/National-support-for-renewable-electricityand-the-single-market-in-Europe-the-\%C3\%85lands-Vindkraft-case.pdf (accessed 15 January 2017).
} 
Commission's public consultation as it 'could imply citizens in one Member State having to contribute to renewables' development in another Member State'. ${ }^{142}$ Some Member States have expressed the need for cross-border participation in support schemes to only be done on a voluntary basis.

\section{Conclusions - Towards an EU-wide Policy on the Promotion of Renewable Energy?}

As we have seen, the ambition of the Commission to regulate and coordinate Member State policies to promote production and consumption of renewable energy, combined with its aim to increase the flexibility of Member States in setting their targets, faces essential legal hurdles, both within the EU and under IIAs. As announced by the Commission, the reforms cannot be carried out without significant reforms of the current regulatory framework. ${ }^{143}$ This article has shown that such a reform is likely to shift the 'policy space' of Member States from the current flexibility to design support schemes to a flexibility in setting national targets. We have seen that many Member States are in the process of scaling back their support schemes to the PV solar sector. However, the situation of this sector is a special case and should not necessarily define the policy space needed within other renewables sectors.

The reforms that Member States have undertaken so far demonstrate the problems of scaling back support schemes that investors have relied on for their long term investments. While the Commission is likely to face many of the same challenges, it is the Member States and not the Commission that will be sued by foreign investors under existing IIAs due to the fact that Member States will have to amend their support schemes. Initiatives by the Commission to prevent Member States from paying compensation mandated by investment tribunals, such as in the Micula case, ${ }^{144}$ is likely to further limit the policy space for Member States when scaling back their support schemes, and may lead to significant resistance among Member States against the Commission's proposals for policy reforms.

The case studies have shown the important effects support schemes can have in generating investment, and the detrimental effects that scaling back of support schemes can have for the establishment of new production capacity. Against this background, we may ask whether the Commission proposals are likely to increase production and consumption of renewable energy. On the basis of the case studies, it can be argued that the current policy space may lead to long term ineffectiveness of support schemes. Stricter state aid rules and rules regarding free movement of products would most likely have prevented Member States from designing such support schemes. However, whether such rules will promote long term effectiveness of support schemes remains unclear. The 'carrot' that the Commission proposals include for Member States - the flexibility in setting and achieving national targets - is not likely to enhance the effectiveness of national policy measures in promoting renewable energy.

All the above factors point in the direction of increased reliance on the EU as responsible for designing and implementing measures to promote renewable energy. Yet, such transfer of competence would further restrict the policy space of Member States. The recent public consultation on a post 2020 renewables directive highlights that this restricted policy space

\footnotetext{
${ }^{142}$ European Commission, Public Consultation, supra n 32, 3.

${ }^{143}$ European Commission, Report from the Commission, supra n 88.

${ }^{144}$ See supra n 111.
} 
may be a cost required for the improved effectiveness of support schemes. A large number of respondents stated that support schemes should 'encourage greater market responsiveness, resulting in gradually decreasing support levels as technologies become mature'; ${ }^{145}$ and that harmonized rules for support schemes at the EU level will be key in providing more certainty to investors and will be the most cost-effective means of achieving the 2030 target. Regardless of how much future competence is vested at the EU level in relation to support schemes, it is fairly clear that we will continue to see significant shifts in the way that support schemes for renewable energy are designed as the EU and its Member States try to get the balance right.

${ }^{145}$ European Commission, Public Consultation, supra n 32, 3. 